The relationship between stock prices, house prices and consumption in OECD countries

Alexander Ludwig and Torsten Sløk

44-2004 


\title{
The relationship between stock prices, house prices and consumption in OECD countries*
}

\author{
Alexander Ludwig \\ MEA, University of Mannheim \\ and \\ Torsten Sløk \\ OECD, Paris \\ First Version: January, 2002 \\ This Version: February, 2004
}

\begin{abstract}
This paper analyzes the relationship between stock prices, house prices and consumption using data for 16 OECD countries. The panel data analysis suggests that the long-run responsiveness of consumption to permanent changes in stock prices is higher for countries with a market-based financial system than for countries with a bank-based financial system. Splitting the sample into the 1980s and 1990s further shows an increased sensitivity in the 1990's of consumption to permanent changes in stock prices for both countries with bank-based financial systems as well as countries with market-based financial systems. The relationship between changes in consumption and changes in house prices is positive for the second sample period across all specifications and financial systems.
\end{abstract}

\footnotetext{
*Correspondence to: Alexander Ludwig, MEA, University of Mannheim; L13,17; 68131 Mannheim; Germany. Phone: +49-621-181-1866, Fax:+49-621-181-1863, Email: alexander.ludwig@mea.unimannheim.de
} 


\section{Introduction}

This paper examines the relationship between stock prices, house prices and private consumption across OECD countries. In recent years, the impact of household wealth on consumption, the so-called consumption-wealth effect, has received increased attention both among academic researchers as well as policymakers. This renewed interest is in part due to the dramatic increase and subsequent fall of stock prices experienced in the 1990s. Measured in percent of GDP the Anglo-Saxon countries, like the United States, have experienced the strongest gains and have consequently also been the focus of most studies. For many European countries, the increase in stock market wealth has also been substantial, whereas in Japan, asset prices have fallen through the 1990s, reflecting the protracted downturn of the Japanese economy.

A number of empirical studies, using aggregate or disaggregate data, have analyzed the impact of changes in wealth on consumption, see Poterba (2000) for a review. Among recent macroeconometric approaches are Ludvigson and Steindel (1999), Mehra (2001), Davis and Palumbo (2001) and Lettau and Ludvigson (2004). Like most empirical studies on the consumption wealth channel, all of these studies focus on the United States. Ludvigson and Steindel (1999), Mehra (2001) and Davis and Palumbo (2001) distinguish between stock market wealth and all other sources of wealth, whereas Lettau and Ludvigson (2004) focus on total wealth only. All of these studies find that a dollar increase in aggregate wealth leads to an increase in aggregate consumption of 3 to 5 cents, a point estimate of the marginal propensity to consume out of wealth that is consistent with the early academic work of Modigliani (1971). As Lettau and Ludvigson (2004) point out, these point estimates only refer to permanent changes in wealth and they find that most changes in wealth are transitory. Against this background we shall interpret our findings as reflecting the relationship between changes in consumption and permanent changes in wealth.

While movements in financial wealth have been dominated by movements in stock market wealth, housing wealth is the single most important component of non-financial wealth in households' portfolios. Due to pronounced increases in housing wealth and deregulation of mortgage markets, there are good reasons to believe that housing wealth may have similar effects on the real economy as stock market wealth. Renewed interest in the relationship between housing wealth (house prices) and consumption is not least due to Greenspan (2001), who suggested that the marginal propensity to consume out of housing wealth might be higher than the marginal propensity to consume out of stock market wealth. The relationship of house prices is the focus of Miles (1992 and 1995) and more recently of Girouard and Blöndal (2001) as well as Aoki et al. (2003) who emphasize that the linkage between house prices and consumption may have changed due to deregulations of mortgage markets which made it easier for households to access their housing wealth.

Relatively few empirical studies specifically distinguish between the wealth effects of stock market and housing wealth. Case et al. (2001), Dvornak and Kohler (2003) and this paper are the only such studies we are aware of. Case et al. (2001) and Dvornak and Kohler (2003) investigate the impact of stock market as well as housing wealth using state level panel data for the United States and Australia respectively and 
construct housing wealth using data on ownership and price indices. While Case et al. (2001) report a higher coefficient estimate for housing wealth than for stock market wealth for most of their specifications, Dvornak and Kohler (2003) find the opposite result. Case et al. (2001) further extend their analysis to a panel of OECD countries. Our analysis contributes to the existing literature by taking the same broad perspective of investigating the relative importance of both wealth components - housing and stock market wealth - using quarterly data for a panel of 16 OECD countries.

We apply the panel data technique for cointegrated panels developed by Pesaran et al. (1999) to the analysis of the relationship between consumption and the two wealth components. This approach allows us to distinguish between short-run and long-run relationships of the data. Our econometric framework is therefore much more flexible than the one used by Case et al. (2001) and we can conduct a much richer empirical analysis along a number of dimensions. Our benchmark specification pools all countries and all time periods. We then proceed by splitting the sample into two different groups of countries and two different time periods. Both sample splits are motivated by the consideration that the structure of the financial system may play a crucial role for the transmission of changes in asset prices to changes in consumption. We therefore distinguish between bank-based and market-based financial systems. The market-based financial system, prevalent in Anglo-Saxon countries, is characterized by a larger size of stock markets and a higher degree of stock market capitalization than in bank-based financial systems, which exist in Continental Europe. This suggests that the responsiveness of consumption to changes in stock prices is higher for the former group of countries. Furthermore, the size of the stock market has increased substantially across time for both groups of countries and deregulations of mortgage markets may have increased transparency and liquidity of real estate markets. Hence we expect the responsiveness of consumption to changes in asset prices to have increased over time which motivates our split of the sample into the 1980s and 1990s.

Instead of constructing wealth data, we use price indices as proxies for stock market and housing wealth and thereby exploit the quarterly frequency of our data. But the use of price data as proxies is of course a limitation of the statistical analysis in this paper. Additional limitations are as follows: First, quarterly data on house prices are not available on such a broad basis of countries and we therefore interpolate between annual observations. Second, in a cross-section of countries, common influences across observations result in non-independence of error terms which is ruled out by our econometric procedure. We therefore follow an approach commonly used in the literature to remove such dependency by including factors that are assumed to influence all countries. Third, views on the role between asset prices and real economic activity differ widely in the literature. At one end of the spectrum it has been argued that observed correlations between asset prices and consumption expenditures are due to the role of asset prices as "leading indicators", see, e.g., Poterba and Samwick (1995). According to this view, asset prices reflect future output growth which explains the correlation with consumption expenditures. At the other end of the spectrum it is argued that the observed correlation is due to real wealth effects. Our analysis follows this second interpretation.

Previewing results of the paper, our findings are as follows. First, we find differences in the role of stock market prices between countries with market-based financial systems 
as compared to countries with bank-based financial systems. Second, while differences between the two country groups remain stable, estimated long run elasticities on stock prices have increased over time which reflects the increased importance of stock market wealth and deregulations of financial markets. Third, our evidence regarding the relative importance of house prices compared to stock prices is mixed and not robust across specifications.

The paper is organized as follows. The econometric model is presented and discussed in Section 2. Section 3 briefly describes our data, data sources and imputations, presents results of unit root and cointegration tests and then continues with our main empirical findings. Section 4 concludes, discusses limitations of the approach chosen and proposes avenues of future research.

\section{The econometric model}

Macroeconomic specifications of the consumption function traditionally explain consumption by income and wealth. The main focus of this paper is the relative importance of two wealth components, stock market and housing wealth, across different countries. A simple model of an aggregate consumption function with household (labor) income and wealth as the only determinants of consumption is motivated by several theories, including the permanent income theory by Friedman (1957) and the life cycle theory by Modigliani and Brumberg (1954) and Ando and Modigliani (1963). In most empirical studies of the wealth effect of consumption, a common trend among the three variables is assumed and tested for. Gali (1990) provides a theoretical foundation for such a formulation. In this paper it is first tested if such a cointegrating relationship exists between consumption, income, and the two wealth measures. Next, an error correction specification of a consumption function as first proposed by Davidson et al. (1978) is estimated for a sample of 16 OECD countries using panel data techniques.

The literature on inference in dynamic and cointegrated panels has evolved rapidly over the past few years. Among various estimators suggested in the literature, the pooled mean group (PMG) estimator proposed by Pesaran et al. (1999) is particularly attractive since it pools long run relationships between countries while short run responses are flexible and unrestricted across countries. Averages of unrestricted short run coefficients are computed as mean group (MG) estimates (Pesaran and Smith 1995). Therefore, the likelihood-based PMG estimation procedure is an intermediate procedure between pooling panel data and fully unconstrained estimation.

Our analysis departs from assuming a long run relationship between consumption, income and the two wealth components, stock market and housing wealth, given by

$$
c_{t, i}=\alpha_{0 i}+\alpha_{1 i} y_{t, i}^{d}+\alpha_{2 i} w_{t, i}^{s w}+\alpha_{3 i} w_{t, i}^{h w}+\epsilon_{t, i} \text { for } i=1, \ldots, N ; t=1, \ldots, T_{i},
$$

where $c_{t, i}$ is $\log$ private per capita consumption, $y_{t, i}^{d}$ is log per capita disposable income, $w_{t, i}^{s w}$ and $w_{t, i}^{s m}$ refer to log stock market wealth and log per capita housing wealth respec- 
tively and subscripts $i$ and $t$ denote country and time. ${ }^{1} \epsilon_{t, i}$ is the error term capturing the effects of unexpected shocks to consumption. ${ }^{2}$

Deviations from the long run relationship given by equation (1) are possible in the short run. There are various reasons for such deviations including adjustment costs, habit persistence and liquidity constraints, see, e.g., Mehra (2001). Our econometric specification allows for different (short run) consumption functions across countries which is formally implemented by determining the lag length of each variable by conventional statistical criteria. But for ease of presentation we shall assume here that only the first lag of each variable is relevant for the short run relationship in each country. The $\operatorname{ARDL}(1,1,1,1)$ specification of equation (1) is accordingly given by

$$
c_{t, i}=\delta_{i}+\beta_{10 i} y_{t, i}^{d}+\beta_{11 i} y_{t-1, i}^{d}+\beta_{20 i} w_{t, i}^{s w}+\beta_{21 i} w_{t-1, i}^{s w}+\beta_{30 i} w_{t, i}^{h w}+\beta_{31 i} w_{t-1, i}^{h w}+\gamma_{i} c_{t-1, i}+\eta_{t, i}
$$

The error term, $\eta_{t, i}$, is assumed to be independently distributed across $t$ and $i$ but the variances may be heterogeneous across countries. The cross-sectional independence assumption of the error term is restrictive. For example, it is not hard to imagine shocks that affect all countries at the same time. The implications of this assumption for our statistical results is discussed in Section 3.3 where results of an alternative specification aiming at removing such dependence are presented.

Rewriting equation (2) gives the error correction specification as:

$$
\begin{array}{r}
\Delta c_{t, i}=\phi_{i}\left(c_{t-i, i}-\alpha_{0 i}-\alpha_{1 i} y_{t, i}^{d}-\alpha_{2 i} w_{t, i}^{s w}-\alpha_{3 i} w_{t, i}^{h w}\right)+ \\
\beta_{11 i} \Delta y_{t, i}^{d}+\beta_{21 i} \Delta w_{t, i}^{s w}+\beta_{31 i} \Delta w_{t, i}^{h w}+\eta_{t, i}
\end{array}
$$

where $\Delta$ is the first difference operator and

$$
\phi_{i}=-\left(1-\gamma_{i}\right), \alpha_{0 i}=\frac{\delta_{i}}{1-\gamma_{i}}, \alpha_{1 i}=\frac{\beta_{10 i}+\beta_{11 i}}{1-\gamma_{i}}, \alpha_{2 i}=\frac{\beta_{20 i}+\beta_{21 i}}{1-\gamma_{i}}, \alpha_{3 i}=\frac{\beta_{30 i}+\beta_{31 i}}{1-\gamma_{i}} .
$$

Equation (3) is written in terms of current, rather than lagged levels of the exogenous regressors, since this allows an $\operatorname{ARDL}(1,0,0,0)$ specification as a special case, see also Pesaran et al. (1999). Within this framework, Pesaran et al. (1999) suggest to restrict the coefficients of the long run relationship in equation (3) to be equal across countries while all additional short run coefficients in equation (3) are allowed to vary. Hence, $\alpha_{j i}=\alpha_{j}$, for $j=1,2,3$ and $i=1, \ldots, N$. The equation is estimated by maximum likelihood. The restriction of equal long run coefficients across countries can be tested by a conventional likelihood ratio (LR) test. As Pesaran et al. (1999) point out, it is likely that this homogeneity restriction is rejected by the data. One explanation is that there might be sample-specific omitted variables in the individual country regressions or measurement errors that are correlated with the regressors. While it might be possible to correct for such biases in individual country regressions, it is impossible to do so for a panel of countries. If such biases average to zero across groups, then pooling removes such random variation. Under such circumstances, pooling provides a more

\footnotetext{
${ }^{1}$ Note that $T$ has subscript $i$ and hence we allow for an unbalanced panel.

${ }^{2}$ Note that one may also think of the left hand side of equation (1) as planned consumption, see, e.g., Mehra (2001).
} 
reasonable estimate of the true coefficient. If the restriction is wrong and one is interested in the average effect across a certain group of countries, then pooling and thereby ex ante imposing homogeneity might still be more reasonable in small samples. While the MG estimator is sensitive to outliers in small samples, pooling, which weighs the individual country specific heterogeneous coefficients according to precision, reduces such bias. Along this line, the estimated coefficients can be interpreted as the weighted averages of individual group estimators where the weights are determined by the inverses of their variance covariance matrices. ${ }^{3}$

A few further remarks on the econometric procedure are in order: First, the coefficients on the lagged dependent variables in equation (3) are subject to the familiar small sample (small $T$ ) downward bias. Since this downward bias is in the same direction for each group, averaging or pooling does not remove this bias. Second, as Pesaran and Smith (1995) point out, falsely imposing homogeneity in panels leads to an upward bias in the estimates of the coefficients on the lagged dependent variables, a bias that is not reduced when both $T$ and $N$ grow large. It is possible to determine whether such an upward bias is serious. Under slope homogeneity, the PMG estimator is consistent and efficient while the MG estimator is consistent but inefficient. Therefore a Hausman-type test for comparison of the MG and PMG estimators can be applied (Pesaran et al. 1999). Thus there are two biases pointing into opposite directions. However, it is not clear to what degree one bias offsets the other.

\section{Empirical results}

\subsection{Data}

Our panel data set covers 16 OECD countries. Data availability of the unbalanced panel is shown in Table 9 in the Appendix. Due to the broad coverage of our study we face a number of data limitations. First, data on housing wealth is not available on such a broad basis. We therefore use stock market price indices and house price indices as proxy variables for the two wealth components. The (in)direct impact of stock market prices on aggregate consumption has been investigated in a number of studies, e.g., by Romer (1990) and Poterba and Samwick (1995). The role of house prices on consumption is the focus in, e.g., Miles (1992), Miles (1995, chapter 4) and more recently Girouard and Blöndal (2001) as well as Aoki et al. (2003). To underscore the validity of using price data as proxy variables we also document regression results using stock market capitalization data as a more direct measure of stock market wealth in Section 3.3.

Second, all data is available on a quarterly frequency except for house prices which is on an annual frequency. Since we want to exploit the long time dimension of all other variables in our regressions, we linearly interpolate house price data between annual observations. ${ }^{4}$ While we technically treat house price data as quarterly data in our

\footnotetext{
${ }^{3}$ See the discussion in the 1997 working paper version of Pesaran et al. (1999, p. 13).

${ }^{4}$ House price data are reported as year averages. We ensure that quarterly data average to the annual numbers by requiring the first four quarterly data points to match the annual numbers. We proceed by recursive interpolation and drop the first three quarterly data points.
} 
regressions and while our statistical results are robust against alternative interpolation methods such as cubic spline, our interpolated house price data does obviously not contain more information than the original annual data. But given the normally smooth movements in house prices over quarters, the assumption implicit in interpolation does not appear unrealistic.

Third, our data is given for total aggregate consumption and hence we cannot distinguish between non-durable and durable consumption. Conventional theories on consumption apply to the flow of consumption. Since durable consumption can be thought of as a replacement and addition to a capital stock, the approach in some studies is to only use non-durable consumption. ${ }^{5}$ However, as pointed out by Mehra (2001), total consumption is the variable of interest when investigating the consumption-wealth channel. In particular, stock market crashes are more likely to lead to a postponement of durable consumption while the reduction of non-durable consumption might be of minor importance, see Romer (1990). Furthermore, as Brady et al. (2000) point out, durable consumption goods are among the major entities on which resources raised by mortgage refinancing are spend on. As a drawback, total aggregate consumption also includes expenditures on housing services.

Forth, data availability constrains us to use total disposable income instead of only labor income as suggested by the traditional permanent income hypothesis. But the use of total income rather than only labor income is also suggested by several economic theories such as an extended view of the life-cycle theory, see Attanasio (1999), or if households on average are more myopic than the life-cycle theory of consumption suggests, see, e.g., Campbell and Mankiw (1991).

Data on consumption and disposable household income are taken from the OECD Analytical Database (OECD 2001). Data on stock market price indices are taken from the International Financial Statistics (IMF 2001), which provides a relatively broad coverage. House price indices are taken from the Bank for International Settlement's house price database BIS (2001). ${ }^{6}$ All variables are in local currencies and deflated by the consumer price index taken from the OECD Analytical Database. Consumption and income are expressed in per capita units using United Nations population data (United Nations 2000), which are linearly interpolated between annual observations. Logs have been taken of all variables and hence estimates reported below are elasticities of consumption in changes of right hand side variables.

As Engle and Granger (1987) point out, the long-run relationship of equation (3) cannot be consistently estimated if all single variables have unit roots unless the variables in the long-run relationship are cointegrated. We therefore first examine the statistical properties of the data and test whether a cointegrating equilibrium relationship between consumption, income and the two price indices exists. Recently, such tests for unit roots of individual series and cointegrating relationships between series have been developed for panel data to which we turn next. See Baltagi and Kao (2000) for an overview of such tests.

\footnotetext{
${ }^{5}$ See Lettau and Ludvigson (2004) for a discussion.

${ }^{6}$ The comparability of these indices across countries is discussed in Girouard and Blöndal (2001, p. $36)$.
} 


\subsection{Unit root and cointegration tests}

We apply the Im et al. (2003) (IPS) test to test for unit roots. ${ }^{7}$ The IPS t-bar test is based on averages of individual country Augmented Dickey Fuller (ADF) tests which allows for different serial correlation patterns across groups. Under the null hypothesis all groups exhibit a unit root while under the alternative this is not the case for some groups. The standardized Z-bar statistic by Im et al. (2003) converges to a normal distribution. The left tail is used for rejection of the null. Table 1 summarizes results for these unit root tests. Time trends are included in the individual regressions for consumption and income but not for stock and house prices. Lags were chosen by the Schwarz Bayesian Criterion (SBC).

Table 1: IPS panel unit root tests

\begin{tabular}{lc}
\hline Variable & Z-bar test statistic \\
\hline $\log$ of per capita consumption, $c_{t, i}$ & 0.08895 \\
$\log$ of per capita income, $y_{t, i}^{d}$ & 0.44459 \\
$\log$ of stock prices, $w_{t, i}^{s m}$ & 0.57716 \\
$\log$ of house indices, $w_{t, i}^{h m}$ & $-3.30569^{* *}$ \\
\hline
\end{tabular}

Notes: Regressions on income and consumption include time trends. ${ }^{*}(* *)$ denote significance at the 10(5) percent level. Test results are for the sample period of $1960-2000$.

According to our test results the null of a panel unit root is not rejected for consumption, income and stock prices, but it is rejected for house prices. However, due to the heterogeneous nature of the alternative, a rejection of the null hypothesis does not necessarily imply that the null is rejected for all groups (Im et al. 2003, p. 74). We therefore also tested for unit roots using the more restrictive test by Levin and Lin (1992) which restricts the alternative to be homogeneous across groups. For this test the null of a unit root of house prices was not rejected. ${ }^{8}$

We use Pedroni (1999)'s tests for cointegration to test for the null of no cointegration. Pedroni's residual based tests allow for a considerable degree of heterogeneity between groups with regard to the intercept, the error structure, and the cointegrating relationship. Pedroni presents seven tests that can be grouped into two types of statistic. The first type of statistic is based on pooling along the within-dimension of the panel; the second is based on pooling along the between-dimension, see Pedroni (1999, p. 657). The second type of statistic allows for an additional source of heterogeneity across individual panel members since it allows for heterogeneous autoregressive coefficients of the estimated residuals under the alternative of no cointegration (Pedroni 1999). As further pointed out by Baltagi and Kao (2000), this second type of statistic also allows an easier interpretation of the statistic if the null is rejected. Therefore, Table 4 only summarizes results for the second type of Pedroni's panel cointegration tests for alternative choices of cointegrating variables. ${ }^{9}$ Under the null hypothesis all statistics asymptotically con-

\footnotetext{
${ }^{7}$ We implement these tests using the NPT 1.3 program developed by Chiang and Kao (2002).

${ }^{8}$ Results available upon request.

${ }^{9}$ Results for the first type of test statistic are similar and are available upon request.
} 
verge to a standard normal distribution. Under the alternative hypothesis, the statistics diverge to negative infinity, see Pedroni (1999, p. 668). Therefore, the left tail of the normal distribution is used for rejection of the null. Table 2 first shows test results for the null of no cointegrating relationship between income, stock prices and house prices, the variables on the right hand side of equation (1). Next, the table shows test results for our specification of interest (the null of no cointegration between income, consumption and the two price indices). According to the results, the null of no cointegration between consumption, income, stock and house prices is rejected. It is not rejected if consumption is excluded.

Table 2: Pedroni panel cointegration tests

\begin{tabular}{llll}
\hline Regression Specification & $\rho$-Statistic & $t$-Statistic & $a d f$-Statistic \\
\hline$y_{t, i}:$ Income $\left(y_{t, i}^{d}\right)$ & 3.58687 & 2.28910 & -0.23974 \\
$x_{t, 1, i}:$ Stock Market Price Index $\left(w_{t, i}^{s m}\right)$ & & & \\
$x_{t, 2, i}:$ house price Index $\left(w_{t, i}^{h m}\right)$ & & & \\
\hline$y_{t, i}:$ Consumption $\left(c_{t, i}\right)$ & $-2.83991^{* *}$ & $-3.77354^{* *}$ & $-2.34852^{* *}$ \\
$x_{t, 1, i}:$ Income $\left(y_{t, i}^{d}\right)$ & & & \\
$x_{t, 2, i}:$ Stock Market Price Index $\left(w_{t, i}^{s m}\right)$ & & \\
$x_{t, 3, i}:$ house price Index $\left(w_{t, i}^{h m}\right)$ & & \\
\hline
\end{tabular}

Notes: ${ }^{*}(*)$ denote significance at the $10(5)$ percent level. Test results are for the sample period of $1960-2000$.

\subsection{Estimating consumption equations}

A number of theoretical considerations regarding the linkages between consumption and asset prices as well as the role of financial markets during the transmission are discussed in the literature (Case et al. 2001; Ludwig and Sløk 2002). These considerations suggest the following hypotheses: We expect to find (i) a positive relationship between asset prices and consumption, (ii) a higher responsiveness of consumption to changes in asset prices for countries with market-based financial systems and (iii) an increase in the responsiveness of consumption to changes in asset prices across time. We address these hypotheses first, by estimating consumption functions given by equation (3) for the entire sample period and all countries, second, by splitting the sample into two groups of countries with bank-based and market-based financial systems and third, by splitting the sample into two sub-periods.

For splitting our sample into two groups of countries we follow the criteria of Borio (1996) who provides an analysis of credit market characteristics in fourteen industrialized countries. More specifically, we include Belgium, Denmark, Finland, France, Germany, Italy, Japan, Norway and Spain among the group of economies with bank-based financial systems whereas we treat Australia, Canada, Ireland, the Netherlands, Sweden, the United Kingdom and the United States as market-based economies. Including Sweden and the Netherlands among the group of market-based (anglo-saxon) economies is moti- 
vated by the relatively large stock market participation in those two countries. ${ }^{10}$ While suggested by such criteria, our sample split is ad hoc and an endogenous grouping of countries according to more explicit measures for the financial system would certainly be warranted. The same critique applies to our second sample split across time which we arbitrarily set at $1985 .{ }^{11}$ We further discuss these limitations of our approach in the conclusions.

In principle, the investigation of the data properties in Section 3.2 implies that estimation of equation (3) with variables expressed in log levels provides reliable inference about the long and short term influences of income, stock market and house price indices on consumption. However, our econometric approach has a number of limitations: (i) the assumptions needed to interpret consumption functions structurally are highly implausible, (ii), as mentioned in Section 3.1, we face a number of data limitations and (iii) there are several reasons why standard errors reported below could be too low. ${ }^{12}$ Too low values of standard errors may result from first, the use of price indices instead of actual wealth data. While price series and wealth series are highly correlated, see, e.g., Lettau and Ludvigson (2004), there is some uncertainty in mapping the growth rates of price indices to the growth rate of (unobserved) household wealth - an uncertainty that is not included in the standard errors reported below. Second, by using interpolated observations on annual house price series and by interpreting these interpolated observations as additional observations, our statistical analysis pretends to have at most 60 observations per country when we in fact have only at most 15 observations. Third, the cross-sectional independence assumption on error terms in equation (2) may be violated since we are dealing with such integrated countries. Since our regression results ignore such dependence, reported standard errors are probably too low. For this reason, we first present results without correcting for such cross-sectional dependence (Specification I). We then proceed by including aggregate GDP across all countries as a proxy for common factors that affect all countries (Specification II). As an additional sensitivity check of our analysis, we further present results of a regression using stock market capitalization data instead of price data (Specification III).

\section{Specification I: No common factors}

Table 3 provides estimates for the entire sample period, 1960-2000, and Table 4 for our two sub-sample periods, 1960 to 1984 and 1985 to 2000. The second column of each table shows results for a regression including all countries, the third and the forth columns show results for the group of bank-based and market-based economies respectively. We determine the lag length of the ARDL model by the Schwartz Bayesian criterion (SBC) with a maximum number of four lags for the two sub-sample periods (Table 4). For the combined sample (Table 3), we impose the average lag structure determined for the

\footnotetext{
${ }^{10}$ See Ludwig and Sløk (2002) for more details.

${ }^{11}$ See Lettau and Ludvigson (2004) and the literature cited there for a critical assessment of such sample splits.

${ }^{12}$ We thank an anonymous referee for pointing out these aspects.
} 
two sub-sample periods. ${ }^{13}$ The unweighted average $R^{2}$ of individual restricted country regressions is around 47 percent for all regressions. Individual estimates of fit vary a lot ranging from around 17 percent in case of Australia to 92 percent in case of Ireland (and this pattern is by and large persistent across specifications). The Hausman test statistic is indeterminate since the difference between the variance-covariance matrices of the MG and PMG estimators is not positive definite. ${ }^{14}$

The values of estimated income elasticities are (significantly) positive and less than one across all specifications as suggested by the life-cycle model, see, e.g., Ando and Modigliani (1963) and Gali (1990). Point estimates of the adjustment coefficients are (significantly) negative and hence economies are found to converge back to the long run equilibrium given by the cointegrating relationship between consumption, income and the two wealth components. ${ }^{15}$ Table 3 further shows a (significantly) positive relationship between stock prices and consumption for all countries as well as for the two different sub-groups of countries whereas the house price coefficient estimates are insignificant. Coefficient estimates for stock prices are higher for the group of countries with a marketbased financial system.

These results support the hypothesis of a positive responsiveness of consumption to changes in stock prices which is higher in countries with market-based financial systems. They do however not support the hypothesis of a positive effect of changes in house prices on consumption.

We next turn to an investigation for the two sub-sample periods, 1960-1984 and 1985-2000, reported in Table 4. While the time period is about the same for both subsamples, our unbalanced panel implies less observations for the first sub-sample, see Table 9. Coefficient estimates on the two wealth measures are higher for the second sample period. We even find (significantly) negative coefficient estimates on house prices for the first sample period, but, as shown in Table 6, they are not insensitive against alternative specifications. A tentative interpretation of the higher coefficient estimates on wealth for the second sample period is that wealth has become a relatively more important determinant of consumption which is consistent with deregulations of financial markets and increased stock market participation. For our group of market-based economies, we find an increase in the coefficient of stock market prices from 0.026 to 0.08 while for bank-based economies it increases from an (insignificant) value of 0.006 to a (significant)

\footnotetext{
${ }^{13}$ We experimented with alternative values for the maximum lag length as well as with using Akaike Information Criterion (AIC) instead of SBC. Results were similar for all coefficient estimates across all specifications except for the house price coefficient estimates. The latter reacted sensitive to the lag selection procedure only for the entire sample period 1960-2000. For some specifications it changed sign and - while insignificant for almost all specifications - it was significantly negative for the group of market-based economies when we determined lags by SBC with a maximum number of lags equal to four. By imposing the average lag structure of the two sub-samples on the regression for the entire sample, we first make results comparable across the different sample periods and second, report those results that we obtained for almost all of our specifications.

${ }^{14}$ For reasons discussed in Section 2, we do not report likelihood ratio statistic which reject homogeneity for all of our specifications.

${ }^{15}$ However, our single equation specification does not allow for definite judgment whether this adjustment is really due to consumption, see the discussion between Lettau et al. (2001) and Davis and Palumbo (2001).
} 
Table 3: Estimating aggregate consumption functions (1960-2000)

\begin{tabular}{|c|c|c|c|}
\hline Variable & All countries & Bank-based economies & Market-based economies \\
\hline & \multicolumn{3}{|c|}{ PMG estimates of long run coefficients } \\
\hline \multirow{2}{*}{$y^{d}$} & $0.863^{* *}$ & $0.820 * *$ & $0.878^{* *}$ \\
\hline & $(0.023)$ & $(0.031)$ & $(0.044)$ \\
\hline \multirow{2}{*}{$w^{s m}$} & $0.025^{* *}$ & $0.025^{* *}$ & $0.052^{* *}$ \\
\hline & $(0.005)$ & $(0.006)$ & $(0.010)$ \\
\hline \multirow{3}{*}{$w^{h m}$} & 0.018 & 0.017 & 0.012 \\
\hline & $(0.014)$ & $(0.019)$ & $(0.031)$ \\
\hline & \multicolumn{3}{|c|}{$M G$ estimates of short run adjustment coefficients } \\
\hline \multirow{2}{*}{$\frac{1}{N} \sum_{i=1}^{N} \phi_{i}$} & $-0.089^{* *}$ & $-0.1^{* *}$ & $-0.086^{* *}$ \\
\hline & $(0.022)$ & $(0.032)$ & $(0.033)$ \\
\hline \multicolumn{4}{|c|}{ Diagnostic statistic } \\
\hline $\begin{array}{l}\text { Hausman } \\
\text { (p-value) }\end{array}$ & n.a. & n.a. & n.a. \\
\hline
\end{tabular}

Notes: This table shows regression results of aggregate consumption functions given by equation (3) for the sample period of $1960-2000$. See Table 9 for data availability. The Hausman test statistic for equality of the MG and PMG estimators is indeterminate if the difference between the variancecovariance matrices of the MG and PMG estimators is not positive definite (Pesaran et al. 1999). Standard errors of the estimated coefficients are given in parentheses. ${ }^{*}(* *)$ denote significance at the 10(5) percent level.

value of 0.03. An - again tentative - interpretation of this result is that the responsiveness of consumption to changes in stock market wealth has both increased over time and is higher for the group of market-based economies. These findings are consistent with the notion of a higher degree of stock market participation and capitalization as well as more deregulated financial markets in countries with market-based financial systems.

While the Hausman test is again indeterminate for the first sample period, the null of equality of the mean group and pooled mean group estimators is not rejected by the Hausman test at conventional levels of significance for the second sample period and for all countries as well as the group of bank-based economies. This implies that pooled estimates are not biased by the imposition of homogeneity and that standard errors are reduced. For the group of market-based economies the null of equality is not rejected at a five percent level of significance.

Among several robustness checks, we tested the robustness of the house price estimates with regard to alternative interpolation procedures such as cubic spline interpolation. Also, for a smaller sub-sample of countries, quarterly house price data was available. ${ }^{16}$ For this small set of countries (Germany, Italy, Spain, Sweden and the United Kingdom) and a slightly shorter time series, the estimates confirmed the positive influence of changes in house prices on consumption that we found for the second sample period.

\footnotetext{
${ }^{16}$ We thank Matteo Iacoviello (European Central Bank) for providing us with the data.
} 
Table 4: Estimating aggregate consumption for different sample periods

\begin{tabular}{lccc}
\hline Variable & All countries & Bank-based economies & Market-based economies \\
\hline \hline \multicolumn{3}{c}{ Sample period 1960-1984 } \\
\hline \multirow{2}{*}{$y^{d}$} & $0.917^{* *}$ & $0.905^{* *}$ & $0.914^{* *}$ \\
& $(0.016)$ & $(0.019)$ & $(0.027)$ \\
$w^{s m}$ & $0.015^{* *}$ & 0.006 & $0.026^{* *}$ \\
& $(0.004)$ & $(0.006)$ & $(0.008)$ \\
$w^{h m}$ & $-0.054^{* *}$ & $-0.038^{* *}$ & -0.028 \\
& $(0.013)$ & $(0.018)$ & $(0.023)$ \\
\hline \multirow{2}{*}{$\frac{M G}{N} \sum_{i=1}^{N} \phi_{i}$} & $-0.213^{* *}$ & $-0.218^{* *}$ estimates of short run adjustment coefficients & $-0.223^{* *}$ \\
& $(0.051)$ & $(0.074)$ & $(0.078)$
\end{tabular}

Diagnostic statistic

\begin{tabular}{|c|c|c|c|}
\hline $\begin{array}{l}\text { Hausman } \\
\text { (p-value) }\end{array}$ & n.a. & n.a. & n.a. \\
\hline & \multicolumn{3}{|c|}{ Sample period 1985-2000 } \\
\hline & \multicolumn{3}{|c|}{$P M G$ estimates of long run coefficients } \\
\hline \multirow{2}{*}{$y^{d}$} & $0.703^{* *}$ & $0.644^{* *}$ & $0.706^{* *}$ \\
\hline & $(0.023)$ & $(0.047)$ & $(0.028)$ \\
\hline \multirow{2}{*}{$w^{s m}$} & $0.080^{* *}$ & $0.03 * *$ & $0.082^{* *}$ \\
\hline & $(0.006)$ & $(0.008)$ & $(0.007)$ \\
\hline \multirow{3}{*}{$w^{h m}$} & $0.036^{* *}$ & 0.015 & $0.040^{*}$ \\
\hline & $(0.012)$ & $(0.019)$ & $(0.022)$ \\
\hline & \multicolumn{3}{|c|}{$M G$ estimates of short run adjustment coefficients } \\
\hline \multirow{2}{*}{$\frac{1}{N} \sum_{i=1}^{N} \phi_{i}$} & $-0.096^{* *}$ & $-0.140^{* *}$ & $-0.128^{* *}$ \\
\hline & $(0.025)$ & $(0.056)$ & $(0.049)$ \\
\hline \multicolumn{4}{|c|}{ Diagnostic statistic } \\
\hline Hausman & 5.62 & 4.09 & 7.67 \\
\hline (p-value) & $(0.13)$ & $(0.25)$ & $(0.054)$ \\
\hline
\end{tabular}

Notes: This table shows regression results of aggregate consumption functions given by equation (3) for the two sub-sample periods 1960-1984 and 1985-2000. See Table 9 for data availability. The Hausman test statistic for equality of the MG and PMG estimators is indeterminate if the difference between the variance-covariance matrices of the $\mathrm{MG}$ and $\mathrm{PMG}$ estimators is not positive definite (Pesaran et al. 1999). Standard errors of the estimated coefficients are given in parentheses. * $(* *)$ denote significance at the 10(5) percent level. 
We next turn to the two probably most important robustness checks by investigating whether our results are robust against controlling for common factors and by using stock market capitalization as an alternative wealth measure.

\section{Specification II: The common factor problem}

An important issue discussed in the literature on dynamic panel estimation and testing is the hypothesis of cross Section independence (Pesaran et al. 1999; Phillips and Sul 2002; Pesaran 2002). Standard errors of our regression results reported in tables 3 and 4 are likely to be downward biased since we do not appropriately correct for such dependence across countries. While econometric techniques taking into account such dependence are still in development, two approaches are commonly used in empirical research. The most conventional way is to include a common time dummy in the regressions and to accordingly run regressions using cross-section demeaned data. The underlying assumption of this approach is that the common factor has the same impact on all countries which is too restrictive in our application. ${ }^{17}$ The alternative is to allow the impact of the common factor to vary across countries (Pesaran et al. 1999; Phillips and Sul 2002). More precisely, we decompose the error term of equation (3) as

$$
\eta_{i, t}=\delta_{i} \theta_{t}+\xi_{i t},
$$

where $\theta_{t}$ is the common factor and assume that $E\left(\eta_{i, t} \eta_{j, t}\right)=\delta_{i} \delta_{j}$ and $E\left(\xi_{i, t} \xi_{j, t}\right)=$ 0 for all $i \neq j$. As a common factor we use the log of total GDP (summed across all countries) per capita (the sum of population across all countries) and report results on these robustness checks in tables 5 and 6 .

A comparison of tables 3 and 5 reveals that, although the regression coefficient on stock prices for the group of market-based economies decreases, results for the entire sample are almost unaffected by the inclusion of the common factor. However, regression results look slightly different for the two sub-periods, compare tables 4 and 6 . First, while the coefficients on stock prices do not differ between these alternative specifications for the first sample period, they are lower for the second sample period especially for the group of market-based economies. Furthermore, we now find positive and significant house price coefficients for the first sample period and the specification including all countries as well as for the group of bank-based economies. Moreover, the coefficient estimates on house prices is virtually indifferent from the coefficient estimates on stock prices for the second sample period.

\section{Specification III: Stock market capitalization data}

Next, we use data on stock market capitalization as an alternative proxy for stock market wealth and accordingly report regression results for the second sample period in Table 7 when including our proxy for the common factor as above. ${ }^{18}$ Coefficient estimates on stock prices are found to be insensitive towards using this alternative measure. ${ }^{19}$

\footnotetext{
${ }^{17}$ Regression results were unstable for regressions using cross-section demeaned data.

${ }^{18}$ The time series of our stock market capitalization data are shorter. Here, we therefore only focus on the second sample period.

${ }^{19}$ They are also insensitive when we do not control for the common factor, see Ludwig and Sløk (2002).
} 
Table 5: Estimating aggregate consumption functions (1960-2000) - controlling for the common factor problem

\begin{tabular}{|c|c|c|c|}
\hline$\overline{\text { Variable }}$ & All countries & Bank-based economies & Market-based economies \\
\hline & \multicolumn{3}{|c|}{ PMG estimates of long run coefficients } \\
\hline \multirow{2}{*}{$y^{d}$} & $0.802^{* *}$ & $0.732^{* *}$ & $0.823^{* *}$ \\
\hline & $(0.023)$ & $(0.033)$ & $(0.044)$ \\
\hline \multirow{2}{*}{$w^{s m}$} & $0.023^{* *}$ & $0.020^{* *}$ & $0.037^{* *}$ \\
\hline & $(0.003)$ & $(0.004)$ & $(0.006)$ \\
\hline \multirow{3}{*}{$w^{h m}$} & 0.001 & 0.012 & 0.014 \\
\hline & $(0.010)$ & $(0.010)$ & $(0.025)$ \\
\hline & \multicolumn{3}{|c|}{ MG estimates of short run adjustment coefficients } \\
\hline$\overline{\frac{1}{N} \sum_{i=1}^{N} \phi_{i}}$ & $\begin{array}{c}-0.139^{* *} \\
(0.023)\end{array}$ & $\begin{array}{c}-0.148^{* *} \\
(0.031)\end{array}$ & $\begin{array}{c}-0.141^{* *} \\
(0.040)\end{array}$ \\
\hline \multicolumn{4}{|c|}{ Diagnostic statistic } \\
\hline $\begin{array}{l}\text { Hausman } \\
\text { (p-value) }\end{array}$ & n.a. & n.a. & n.a. \\
\hline
\end{tabular}

Notes: This table shows regression results of aggregate consumption functions given by equation (3) for the sample period of $1960-2000$. These specifications include the log of aggregate per capita GDP as exogenous regressors. See Table 9 for data availability. The Hausman test statistic for equality of the MG and PMG estimators is indeterminate if the difference between the variance-covariance matrices of the MG and PMG estimators is not positive definite (Pesaran et al. 1999). Standard errors of the estimated coefficients are given in parentheses. ${ }^{*}(*)$ denote significance at the $10(5)$ percent level. 
Table 6: Estimating aggregate consumption functions for different sample periods - controlling for the common factor problem

\begin{tabular}{|c|c|c|c|}
\hline Variable & All countries & Bank-based economies & Market-based economies \\
\hline & \multicolumn{3}{|c|}{ Sample period 1960-1984 } \\
\hline & \multicolumn{3}{|c|}{ PMG estimates of long run coefficients } \\
\hline \multirow{2}{*}{$y^{d}$} & $0.847^{* *}$ & $0.868^{* *}$ & $0.761^{* *}$ \\
\hline & $(0.035)$ & $(0.040)$ & $(0.071)$ \\
\hline \multirow{2}{*}{$w^{s m}$} & $0.018^{* *}$ & 0.014 & $0.028^{* *}$ \\
\hline & $(0.003)$ & $(0.003)$ & $(0.007)$ \\
\hline \multirow{3}{*}{$w^{h m}$} & $0.021^{* *}$ & $0.024^{* *}$ & 0.002 \\
\hline & $(0.008)$ & $(0.008)$ & $(0.024)$ \\
\hline & \multicolumn{3}{|c|}{$M G$ estimates of short run adjustment coefficients } \\
\hline \multirow{2}{*}{$\overline{\frac{1}{N} \sum_{i=1}^{N} \phi_{i}}$} & $-0.319^{* *}$ & $-0.368^{* *}$ & $-0.264^{* *}$ \\
\hline & $(0.040)$ & $(0.051)$ & $(0.078)$ \\
\hline \multicolumn{4}{|c|}{ Diagnostic statistic } \\
\hline \multirow[t]{3}{*}{$\begin{array}{l}\text { Hausman } \\
\text { (p-value) }\end{array}$} & n.a. & n.a. & n.a. \\
\hline & \multicolumn{3}{|c|}{ "Sample period 1985-2000 } \\
\hline & \multicolumn{3}{|c|}{ PMG estimates of long run coefficients } \\
\hline \multirow{2}{*}{$y^{d}$} & $0.760^{* *}$ & $0.509^{* *}$ & $0.678^{* *}$ \\
\hline & $(0.019)$ & $(0.022)$ & $(0.040)$ \\
\hline \multirow{2}{*}{$w^{s m}$} & $0.024^{* *}$ & $0.027^{* *}$ & $0.031^{* *}$ \\
\hline & $(0.003)$ & $(0.004)$ & $(0.006)$ \\
\hline \multirow{3}{*}{$w^{h m}$} & $0.010^{*}$ & $0.032^{* *}$ & $0.031^{*}$ \\
\hline & $(0.005)$ & $(0.007)$ & $(0.020)$ \\
\hline & \multicolumn{3}{|c|}{$M G$ estimates of short run adjustment coefficients } \\
\hline \multirow{2}{*}{$\overline{\frac{1}{N} \sum_{i=1}^{N} \phi_{i}}$} & $-0.380^{* *}$ & $-0.489^{* *}$ & $-0.227^{* *}$ \\
\hline & $(0.085)$ & $(0.130)$ & $(0.068)$ \\
\hline \multicolumn{4}{|c|}{$\overline{\text { Diagnostic statistic }}$} \\
\hline Hausman & 3.37 & 0.14 & 2.41 \\
\hline (p-value) & $(0.34)$ & $(0.99)$ & $(0.49)$ \\
\hline
\end{tabular}

Notes: This table shows regression results of aggregate consumption functions given by equation (3) for the two sub-sample periods $1960-1984$ and $1985-2000$. These specifications include the $\log$ of aggregate per capita GDP as exogenous regressors. See Table 9 for data availability. The Hausman test statistic for equality of the MG and PMG estimators is indeterminate if the difference between the variance-covariance matrices of the MG and PMG estimators is not positive definite (Pesaran et al. 1999). Standard errors of the estimated coefficients are given in parentheses. ${ }^{*}\left({ }^{*}\right)$ denote significance at the $10(5)$ percent level. 
However, coefficient estimates on house prices increase and are now higher than those for stock prices.

Table 7: Estimating aggregate consumption functions (1985-2000) - controlling for the common factor problem and using stock market wealth data

\begin{tabular}{|c|c|c|c|}
\hline Variable & All countries & Bank-based economies & Market-based economies \\
\hline & \multicolumn{3}{|c|}{$P M G$ estimates of long run coefficients } \\
\hline \multirow{2}{*}{$y^{d}$} & $0.638^{* *}$ & $0.379^{* *}$ & $0.586^{* *}$ \\
\hline & $(0.023)$ & $(0.019)$ & $(0.038)$ \\
\hline \multirow{2}{*}{$w^{s m}$} & $0.026^{* *}$ & $0.018^{* *}$ & $0.036^{* *}$ \\
\hline & $(0.003)$ & $(0.003)$ & $(0.006)$ \\
\hline \multirow{3}{*}{$w^{h m}$} & $0.043^{* *}$ & $0.066^{* *}$ & $0.045^{* *}$ \\
\hline & $(0.007)$ & $(0.008)$ & $(0.017)$ \\
\hline & \multicolumn{3}{|c|}{ MG estimates of short run adjustment coefficients } \\
\hline \multirow{2}{*}{$\frac{1}{N} \sum_{i=1}^{N} \phi_{i}$} & $-0.322^{* *}$ & $-0.361^{* *}$ & $-0.268^{* *}$ \\
\hline & $(0.076)$ & $(0.125)$ & $(0.064)$ \\
\hline \multicolumn{4}{|c|}{ Diagnostic statistic } \\
\hline Hausman & 1.41 & 0.21 & 2.82 \\
\hline (p-value) & 0.70 & 0.98 & 0.52 \\
\hline
\end{tabular}

Notes: This table shows regression results of aggregate consumption functions given by equation (3) for the sample period of $1960-2000$. These specifications include the log of aggregate per capita GDP as exogenous regressors and use stock market capitalization data instead of stock prices. See Table 9 for data availability. Standard errors of the estimated coefficients are given in parentheses. ${ }^{*}(* *)$ indicate significance at the $10(5)$ percent level.

Table 8: Marginal propensities to consume out of stock market wealth

\begin{tabular}{lccccccc}
\hline & AU & CA & UK & US & JAP & FR & GE \\
\hline Long-run MPC & 0.023 & 0.023 & 0.013 & 0.018 & 0.013 & 0.014 & 0.019 \\
Short-run MPC & 0.006 & 0.006 & 0.003 & 0.004 & 0.004 & 0.004 & 0.006 \\
\hline
\end{tabular}

Notes: Marginal propensities to consume out of stock market wealth are calculated by multiplying the estimated elasticities for the second sample period 1985-2000 given in Table 4 with the most recent consumption to stock market wealth ratios as measured by stock market capitalization data. Short-run MPCs are calculated by multiplying long-run MPCs with the estimated average adjustment coefficients given in Table 4.

Finally, we translate our coefficient estimates into estimates of marginal propensities to consume (MPC) out of stock market wealth. To this end, the coefficient estimates are multiplied with the recent aggregate consumption to stock market capitalization ratio, compare Lettau and Ludvigson (2004). The short run estimates are accordingly obtained by multiplying the long run estimates with the estimated adjustment coefficient. Table 8 reports such estimates for selected countries. The estimates are slightly lower than values found in other studies and suggest a marginal propensity to consume out of stock market wealth of around 0.02. According to our findings, a permanent one dollar increase 
in stock market wealth therefore causes consumption in the United States to increase by about 2 cents in the long run which translates into a short run adjustment of about 0.4 cents per quarter.

\section{Conclusions}

This paper analyzes the relationship between consumption, income and two important components of household wealth, stock market and housing wealth, on consumption in OECD countries by estimating panel error correction models in the fashion of Pesaran et al. (1999). Due to data limitations, stock market and housing market price indices are used as proxies for the two wealth components. Due to this and other such limitations discussed in Section 3.3, conclusions drawn from the statistical relationships of our regressions are tentative at best. Against this background, our findings can be summarized as follows: First, we find a long-run relationship between stock market prices and private consumption. Second, there are significant short-run adjustments of all endogenous variables - income, stock prices, and house prices on consumption -, i.e., consumption is found to adjust to its long run relationship with lags. Third, the elasticity of consumption spending to changes in stock prices is larger for economies with market-based financial systems than for economies with bank-based financial systems. Fourth, this elasticity has increased over time for both sets of countries. Fifth, our estimates of the elasticity of consumption with respect to changes in house prices are larger in the 1985-2000 period than in the 1960-1984 period. Finally, it is unclear whether the elasticity of consumption spending with respect to house prices is different from that of stock prices.

Our analysis therefore contrasts with both Case et al. (2001), who find a remarkably higher impact of housing wealth for a panel of U.S. states and for a panel of OECD countries, as well as Dvornak and Kohler (2003), who find a lower impact of housing wealth for a panel of Australian states. According to our findings it remains an open research question whether changes in housing or stock market wealth have a higher impact on consumption.

Some additional comments on our statistical analysis are in order. Our grouping of countries into countries with bank-based versus market-based financial systems is ad hoc and it would certainly be preferable to "endogenously" group countries by using data, e.g., on outstanding mortgage loans and public relative to private sector credit (see, e.g., Beck and Levine (2002)). Along the same lines, it would be interesting to extend the analysis by including more direct measures of financial market deregulations. Moreover, our econometric procedure is subject to a number of limitations which we extensively discuss in Section 3.3 and which are mostly due to data reasons. But beyond that, we allow for only one cointegrating relationship between variables. A panel VAR approach as recently suggested by Larsson et al. (2001) and Larsson and Lyhagen (1999), would allow further insights into the potentially different roles between the two groups of countries that other variables play in restoring the long run equilibrium in the spirit of Lettau and Ludvigson (2001). 


\section{Acknowledgements}

This paper is a significant revision of our 2002 IMF working paper, Ludwig and Sløk (2002). We are especially grateful to two anonymous referees for their detailed comments on our earlier draft. Further helpful comments by Tam Bayoumi, Hali Edison, Zhu Feng, Robert Flood, Doug Laxton, Guy Meredith, Anders Sørensen, Matthias Weiss, Joachim Winter, and several seminar participants at the IMF Research Department and the University of Mannheim are gratefully acknowledged. Alexander Ludwig thanks the Volkswagenstiftung and the Gesamtverband der Deutschen Versicherungswirtschaft (GDV) for financial support. 


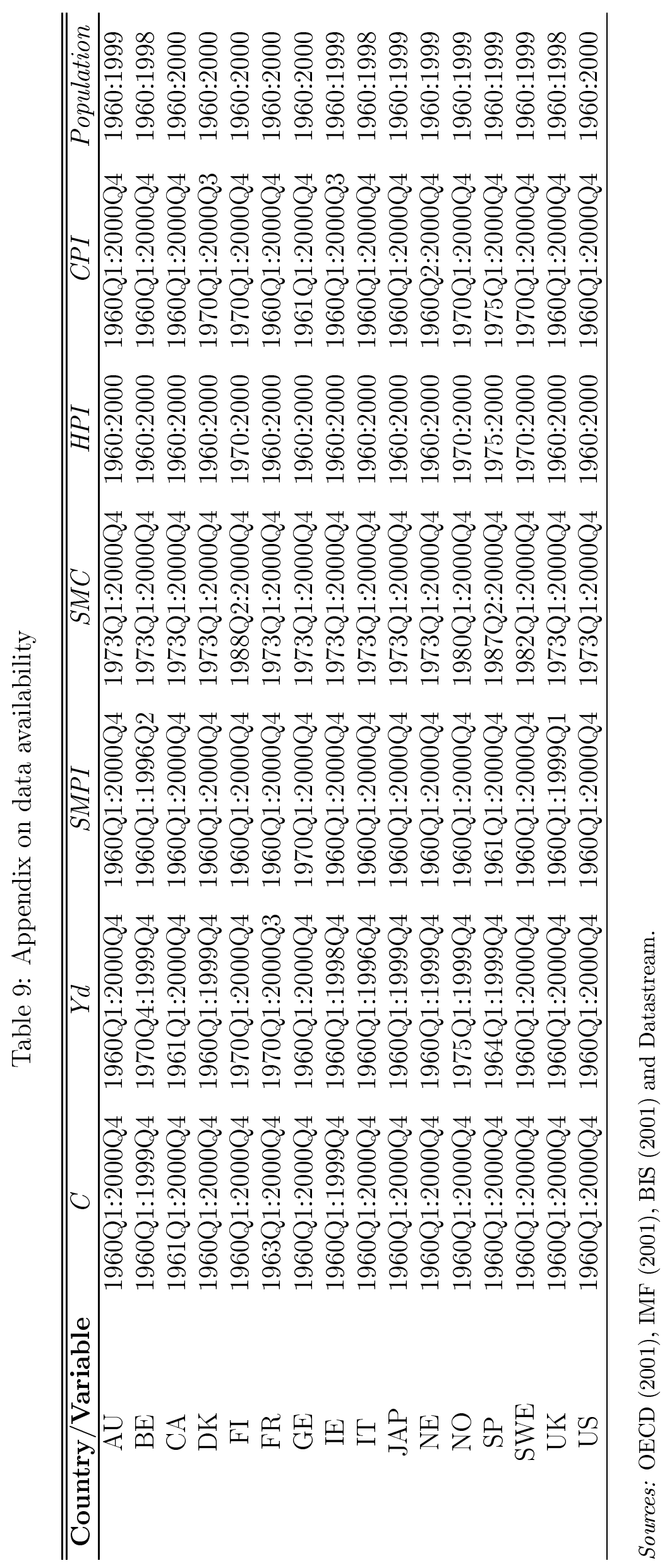




\section{References}

Ando, A. and F. Modigliani (1963). The 'life-cycle' hypothesis of saving: Aggregate implications and tests. American Economic Review 53, 55-84.

Aoki, K., J. Proudman, and G. Vlieghe (2003). Houses as collateral: Has the link between house prices and consumption in the U.K. changed? FRBNY Economic Policy Review. forthcoming.

Attanasio, O. P. (1999). Consumption. In J. B. Taylor and M. Woodford (Eds.), Handbook of Macroeconomics, Volume 1b, Chapter 11, pp. 741-812. Amsterdam: Elsevier Science B. V.

Baltagi, B. H. and C. Kao (2000). Nonstationary panels, cointegration in panels and dynamic panels: A survey. In B. H. Baltagi (Ed.), Nonstationary Panels, Panel Cointegration, and Dynamic Panels, pp. 7-51.

Beck, T. and R. Levine (2002). Industry growth and capital allocation: Does having a market- or bank-based system matter? Journal of Financial Economics 64 (2), $147-180$.

BIS (2001). House price database. Bank for International Settlements, Basel.

Borio, C. E. V. (1996). Credit characteristics and the monetary policy transmission in fourteen industrial countries: Facts, conjectures and some econometric evidence. In K. Alders, K. Koedijk, C. Kool, and C. Winder (Eds.), Monetary Policy in a Converging Europe, pp. 77-115. the Netherlands: Kluwer Academic Publishers.

Brady, P. J., G. B. Canner, and D. M. Maki (2000). The effects of recent mortgage refinancing. Federal Reserve Bulletin, July.

Campbell, J. Y. and N. G. Mankiw (1991). The response of consumption to income: A cross-country investigation. European Economic Review 35, 723-756.

Case, K., R. Shiller, and J. Quigley (2001). Comparing wealth effects: The stock market versus the housing market. NBER Working Paper No. 8606.

Chiang, M. H. and C. Kao (2002). Nonstationary panel time series using NPT 1.3 - a user guide. Unpublished Manuscript, Center for Policy Research, Syracuse University.

Davidson, J. E. H., D. F. Hendry, F. Srba, and F. Yeo (1978). Econometric modelling of the aggregate time-series relationship between consumers' expenditure and income in the United Kingdom. The Economic Journal 88, 661-692.

Davis, M. A. and M. G. Palumbo (2001). A primer on the economics and time series econometrics of wealth effects. Finance and Economics Discussion Series, 2001-09, Federal Reserve Board, Washington, D.C.

Dvornak, N. and M. Kohler (2003). Housing wealth, stock market wealth and consumption: A panel analysis for Australia. Research Discussion Paper 2003-07, Economic Research Department, Reserve Bank of Australia.

Engle, R. F. and C. W. J. Granger (1987). Co-integration and error correction: Representation, estimation, and testing. Econometrica 55 (2), 251-276. 
Friedman, M. (1957). A Theory of the Consumption Function. Princeton, NJ: Princeton University Press.

Gali, J. (1990). Finite horizons, life-cycle savings, and time-series evidence on consumption. Journal of Monetary Economics 26, 433-452.

Girouard, N. and S. Blöndal (2001). House prices and economic activity. OECD Economics Department Working Papers No. 279.

Greenspan, A. (2001). Opening remarks at a symposium sponsored by the federal reserve bank of Kansas City. Jackson Hole, Wyoming, August 31.

Im, K. S., M. H. Pesaran, and Y. Shin (2003). Testing for unit roots in heterogenous panels. Journal of Econometrics 115, 53-74.

IMF (2001). International financial statistics. International Monetary Fund, Washington, D.C.

Larsson, R. and J. Lyhagen (1999). Likelihood-based inference in multivariate panel cointegration models. Working Paper, Stockholm University.

Larsson, R., J. Lyhagen, and M. Løthgren (2001). Likelihood-based cointegration tests in heterogeneous panels. Econometrics Journal 4, 109-142.

Lettau, M., S. Ludvigson, and N. Barczi (2001). A primer on the economics and time series econometrics of wealth effects: A comment. Working Paper, Federal Reserve Bank of New York.

Lettau, M. and S. C. Ludvigson (2001). Consumption, aggregate wealth and expected stock returns. Journal of Finance 56 (3), 815-849.

Lettau, M. and S. C. Ludvigson (2004). Understanding trend and cycle in asset values: Reevaluating the wealth effect on consumption. American Economic Review. forthcoming.

Levin, A. and C.-F. Lin (1992). Unit root tests in panel data: Asymptotic and finitesample properties. Working Paper No 92-23, University of California, San Diego.

Ludvigson, S. and C. Steindel (1999). How important is the stock market effect on consumption. FRBNY Economic Policy Review July, 29-51.

Ludwig, A. and T. Sløk (2002). The impact of changes in stock prices and house prices on consumption in OECD countries. IMF Working Paper, WP 02/01.

Mehra, Y. P. (2001). The wealth effect in empirical life-cycle aggregate consumption equations. Federal Reserve Bank of Richmond Economic Quarterly 87 (2), 45-68.

Miles, D. K. (1992). Housing markets, consumption and financial liberalization in the major economies. European Economic Review 36, 1093-1136.

Miles, D. K. (1995). Housing, Financial Markets and the Wider Economy. Chichester: John Wiley \& Sons.

Modigliani, F. (1971). Consumer spending and monetary policy: The linkages. Federal Reserve Bank of Boston Conference Series 5. 
Modigliani, F. and R. Brumberg (1954). Utility analysis and the consumption function: An interpretation of cross-section data. In K. K. Kurihara (Ed.), Post-Keynesian Economics. New Brunswick, NJ.: Rutgers University Press.

OECD (2001). Analytical database. Organization for Economic Cooperation and Development, Paris.

Pedroni, P. (1999). Critical values for cointegration tests in heterogeneous panels with multiple regressors. Oxford Bulletin of Economics and Statistics Special Issue, 653670.

Pesaran, H. M. (2002). Estimation and inference in large heterogeneous panels with cross section dependence. DAE Working Paper No. 0305, University of Cambridge.

Pesaran, M. H., Y. Shin, and R. P. Smith (1999). Pooled mean group estimation of dynamic heterogeneous panels. Journal of the American Statistical Association 94, 621-634.

Pesaran, M. H. and R. P. Smith (1995). Estimating long-run relationships from dynamic heterogeneous panels. Journal of Econometrics 68, 79-113.

Phillips, P. C. B. and D. Sul (2002). Dynamic panel estimation and homogeneity testing under cross section dependence. Cowles Foundation Discussion Paper No. 1362, Yale University.

Poterba, J. M. (2000). Stock market wealth and consumption. Journal of Economic Perspectives 13, 91-118.

Poterba, J. M. and A. A. Samwick (1995). Stock ownership patterns, stock market fluctuations, and consumption. Brookings Papers on Economic Activity 2, 295-357.

Romer, C. (1990). The great crash and the onset of the great depression. Quarterly Journal of Economics 105, 597-624.

United Nations (2000). World Population Prospects: The 1998 Revision. New York: United Nations Population Division. 


\section{Discussion Paper Series}

Mannheim Research Institute for the Economics of Aging Universität Mannheim

To order copies, please direct your request to the author of the title in question.

\begin{tabular}{|c|c|c|c|}
\hline Nr. & Autoren & Titel & Jahr \\
\hline 31-03 & $\begin{array}{l}\text { Barbara Berkel } \\
\text { Axel Börsch-Supan }\end{array}$ & $\begin{array}{l}\text { Renteneintrittsentscheidungen in Deutschland: } \\
\text { Langfristige Auswirkungen verschiedener } \\
\text { Reformoptionen }\end{array}$ & 03 \\
\hline $32-03$ & $\begin{array}{l}\text { Axel Börsch-Supan, } \\
\text { Hendrik Jürges, } \\
\text { OliverLipps } \\
\end{array}$ & $\begin{array}{l}\text { SHARE: Building a Panel on Health, Aging and } \\
\text { Retirement in Europe }\end{array}$ & 03 \\
\hline 33-03 & Florian Heiss & $\begin{array}{l}\text { Wie groß soll die Schwankungsreserve der } \\
\text { gesetzlichen Rentenversicherung sein? }\end{array}$ & 03 \\
\hline $34-03$ & $\begin{array}{l}\text { Axel Börsch-Supan, } \\
\text { Christina B. Wilke }\end{array}$ & $\begin{array}{l}\text { The German Public Pension System: } \\
\text { How it Was, How it Will Be }\end{array}$ & 03 \\
\hline $35-03$ & $\begin{array}{l}\text { Lothar Essig, } \\
\text { Anette Reil-Held }\end{array}$ & Chancen und Risiken der „Riester-Rente“ & 03 \\
\hline $36-03$ & $\begin{array}{l}\text { Barbara Berkel } \\
\text { Axel Börsch-Supan }\end{array}$ & $\begin{array}{l}\text { Pension Reform in Germany: } \\
\text { The Impact on Retirement Decisions }\end{array}$ & 03 \\
\hline $37-03$ & $\begin{array}{l}\text { Axel Börsch-Supan, } \\
\text { Anette Reil-Held and } \\
\text { Christina Benita } \\
\text { Wilke }\end{array}$ & $\begin{array}{l}\text { How to make a Defined Benefit System } \\
\text { Sustainable: } \\
\text { The "Sustainability Factor" in the German Benefit } \\
\text { Indexation Formula }\end{array}$ & 03 \\
\hline $38-03$ & Melanie Lührmann & $\begin{array}{l}\text { Demographic Change, Foresight and International } \\
\text { Capital Flows }\end{array}$ & 03 \\
\hline 39-03 & $\begin{array}{l}\text { Joachim Winter and } \\
\text { Lothar Essig }\end{array}$ & $\begin{array}{l}\text { Item nonresponse to financial questions in } \\
\text { household surveys: An experimental study of } \\
\text { interviewer and mode effects }\end{array}$ & 03 \\
\hline $40-03$ & Christoph Buchheim & $\begin{array}{l}\text { Das Zusammenspiel von Wirtschaft, Bevölkerung } \\
\text { und Wohlstand aus historischer Sicht }\end{array}$ & 03 \\
\hline $41-03$ & Oliver Lipps & $\begin{array}{l}\text { Stochastische Bevölkerungsprognose für West- } \\
\text { und Ostdeutschland }\end{array}$ & 03 \\
\hline $42-03$ & Axel Börsch-Supan & $\begin{array}{l}\text { What are NDC Pension Systems? What Do They } \\
\text { Bring to Reform Satrategies? }\end{array}$ & 03 \\
\hline 43-04 & Matthias Weiss & $\begin{array}{l}\text { Employment of Skill Biased Technological } \\
\text { Change when Benefits are Linked to Per-Capita } \\
\text { Income }\end{array}$ & 04 \\
\hline $44-04$ & $\begin{array}{l}\text { Alexander Ludwig } \\
\text { and Torsten Sløk }\end{array}$ & $\begin{array}{l}\text { The relationship between stock prices, house } \\
\text { prices and consumption in OECD countries }\end{array}$ & 04 \\
\hline
\end{tabular}






